\section{Three Rs could make laboratories a better place for animals}

\section{Munich}

Hundreds of scientists and animal welfare sympathizers last week signed a declaration endorsing the 'three Rs' principle. This advocates reducing the number of animals used in research, replacing animal experiments wherever possible and refining experiments to reduce suffering.

The declaration was circulated at the Third World Congress on Alternatives and Animal Use in the Life Sciences, held in Bologna, Italy, last week. More signatures will be sought from members of scientific societies.

The declaration is not controversial in most western countries: the principle was formulated 40 years ago and has been the basis of discussions between scientists and animal-welfare groups for years. But Michael Balls, head of the European Centre for the Validation of Alternative Methods, based at Ispra in northern Italy, says it will lend formal support to those seeking better treatment of animals in developing countries. Balls was one of the initiators of the declaration.

The total number of animals used has fallen dramatically during the past two decades, as cheaper in vitro methods have been developed to screen drugs and test toxicity. But the number used in basic research has not changed, possibly because of the growing usefulness of transgenic animals. Alison Abbott

\title{
Universities and business
} fight over right to information

\section{Washington}

New guidelines proposed by the White House are unlikely to settle an increasingly rancorous dispute between the US research community and business interests over public access to research data. Both sides say the matter will probably end up in litigation unless Congress amends or erases the law that started the argument.

Researchers and their business opponents have both rejected revised guidelines issued by the White House Office of Management and Budget (OMB) on 18 August. The revisions have been in progress since late last year, when Congress approved an amendment to an appropriations bill by Senator Richard Shelby (Republican, Alabama) which made universities and other nonprofit research institutes subject to the Freedom of Information Act (FOIA).

The amendment is supported by business interests, which believe it will enable them to challenge university research that the government may use to justify various regulations. It has been opposed by the universities, which find it unacceptable that they should be subject to FOIA. They want to keep control of their data and believe the amendment could lead to harassment of researchers.

OMB proposes that FOIA requests could only be made for research that underpins government regulations, and only where the regulations are likely to have an economic impact exceeding \$100 million. Laboratory samples, preliminary analyses, plans for future research, peer reviews, personnel and medical files, trade secrets and intellectual property would not be accessible.

The Association of American Universities, which represents most of the top research universities, says the revision is too vague about who will pay compliance costs. The universities want to retain the right to decide what material can be sent to the agencies, and are concerned that intellectual property and the privacy of research subjects will not be adequately protected.

The US Chamber of Commerce, which has championed the Shelby amendment, believes the OMB guidelines have undermined the amendment's intent. "We have trouble with the $\$ 100$ million threshold," says Louis Renjel, a member of the chamber's regulatory affairs staff. "That narrows it down to only one per cent of all regulations the government issues." He says the chamber will insist on the amendment covering all government research grants, in all fields relating to all federal rules and regulations.

The conflict might have been avoided if OMB had kept White House science adviser Neal Lane informed of its negotiations with Shelby late last year. Milton Goldberg, director of the Council of Government Relations, a group representing universities, says: "It's true that OMB dropped the ball here. They probably didn't appreciate the amendment's significance in its early stages.” Wil Lepkowski

\section{Policy reversal puts science on top in New Zealand}

\section{Sydney}

In a late policy change three months before a general election, New Zealand's governing National Party has decided to promote science and innovation as a top priority.

Prime minister Jenny Shipley has launched a five-step package aimed at reversing New Zealand's comparatively weak support for university and industrial research.

Though extra funding is small, the package is a substantial shift from the austere research policies that have characterized the past 14 years under successive governments (Nature 398, 450; 1999).

In recent years, university support has fallen on a per-student basis, while fees have risen. The government jettisoned a target set in 1996 to boost its research expenditure from 0.52 to 0.8 per cent of gross domestic product by 2010, and ignored repeated calls for industrial research incentives.

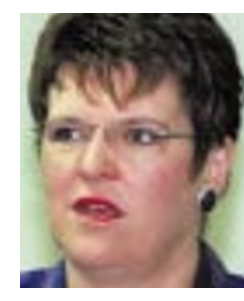

Shipley: reversing years of austerity.
Under the new package, task forces would be set up to examine higher education and tax incentives for industrial research. Eighty scholarships for doctoral students and 26 new postdoctoral fellowships are to be created, with extra funding of NZ\$47 million (US\$24.5 million) over four years.

The National Party currently trails the opposition Labour Party in opinion polls. Labour, led by Helen Clark, has yet to release its election platform, but has said it will include more support for basic research and tax incentives for industrial research. Shadow science minister Mark Peck proposes a new, independent council of scientists to advise the prime minister.
Industry reactions to the package were broadly supportive, while those from academic and science leaders were more mixed.

John Hood, vice-chancellor of Auckland University - New Zealand's largest — welcomed the package as acknowledging "serious weaknesses in the present policy framework". But Daryl Le Grew, vice-chancellor of Canterbury University, dismissed it as "frag-

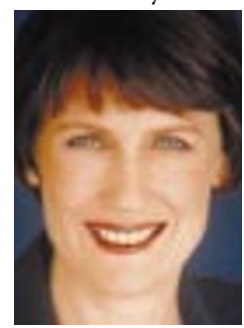

Clark: tax breaks for research? mented and something of a knee-jerk reaction". Andy West, chair of the association of the government-run Crown Research Institutes, said that the change was "most welcome and long overdue" but called for total research expenditure to be doubled or trebled. Peter Pockley 